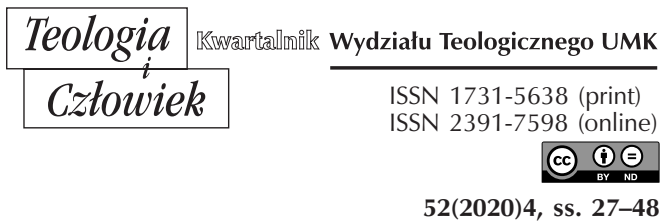

KS. LECH WOŁOWSKI

UNIWERSYTET PAPIESKI JANA PAWŁA II W KRAKOWIE

LECH.WOLOWSKI@UPJP2.EDU.PL

ORCID 0000-0003-2012-1267

\title{
MARIOLOGIA SPOŁECZNA JÓZEFA TISCHNERA
}

DOI: http://dx.doi.org/10.12775/TiCz.2020.049

Streszczenie: Artykuł podejmuje zagadnienie mariologii społecznej Tischnera. Ten wybitny polski autor znany jest ze swojego zaangażowania społecznego i naukowej refleksji w tym zakresie. Prawie zupełnie nieznana jest jednak jego myśl mariologiczna. Tymczasem właśnie w jego pracach odszukać można wskazówkę, że właściwie uprawiana mariologia może stać się wyjątkowo owocnym impulsem dla prawidłowego rozwoju badań nad relacjami społecznymi. Niniejsza praca podejmuje szczegółowe studium tak postawionego zagadnienia na podstawie trzech prac wymienionego wyżej myśliciela: jego adwentowego kazania maryjnego, Książeczki Pielgrzyma oraz Pomocy w rachunku sumienia.

Słowa kluczowe: mariologia; relacje społeczne; pielgrzymka; rachunek sumienia; Tischner.

Abstract. Social Mariology of Józef Tischner. The article addresses the issue of Tischner's social Mariology. This outstanding Polish author is well known for his social commitment and scientific reflection in this area. However, his Mariological thought is almost completely unknown. It is nevertheless true that precisely in his works one can find a hint that proper Mariological studies can become an extremely fruitful stimulus for the appropriate development of research in the area of social relations. The present work examines this issue based on the following three works of the above mentioned thinker: his Marian Advent sermon, Pilgrim's Book and Help in the Examination of Conscience.

Keywords: Mariology; social relations; pilgrimage; examination of conscience; Tischner. 


\section{WSTĘP}

Niniejsza praca stawia sobie za cel przedstawienie zagadnienia mariologii społecznej w ujęciu, jakie zaproponował ks. prof. Józef Tischner. Refleksja społeczna tego wybitnego myśliciela jest ogólnie znana, a pod względem naukowym już dość dobrze opracowana ${ }^{1}$. Zupełnie inaczej sprawy się mają w przypadku Tischnerowskiej mariologii.

Nawet ci autorzy, którzy skłonni są przyznać Tischnerowi pewne zasługi na polu teologii - biorąc pod uwagę choćby jego wkład w takie dziedziny, jak charytologia, antropologia chrześcijańska i z całą pewnością szeroko rozumiana teologia pastoralna - raczej nie byliby skłonni zaliczyć Tischnera do mariologów ${ }^{2}$. Nie ulega wątpliwości, że nie tylko mariologia, ale w ogólności refleksja nawiązująca do osoby Maryi nie należy do dominujących aspektów myśli Tischnera. Jan Galarowicz zwrócił na to uwagę, zaznaczając, że jest to jeden $\mathrm{z}$ istotnych elementów różniący Tischnera i Jana Pawła II: „W chrześcijaństwie Tischnera - w przeciwieństwie do chrystianizmu Wojtyły - jest słabo obecny wymiar "maryjny»"3.

Wszystko to nie oznacza, że wątek maryjny jest całkowicie w myśli Tischnera nieobecny. Jak zostanie to niżej wykazane obecny jest i to

${ }^{1}$ Na pierwszy plan wysuwają się tu następujące dzieła Tischnera: Etyka solidarności, Znak, Kraków 1981; Nieszczęsny dar wolności, Znak, Kraków 1996; Jak żyć?, TUM, Wrocław 2000. Gdy chodzi o opracowania myśli społecznej Tischnera, warto skonsultować: Jagiełło, J., Zuziak, W. (red.), Bądź wolność Twoja. Józefa Tischnera refleksja nad życiem publicznym, Znak, Kraków 2005; Z. Stawrowski, Solidarność znaczy więź, IMJT, Kraków 2010; W. Rogowski, Dylematy liberalizmu: wokót myślenia politycznego Józefa Tischnera, DUET, Toruń 2013.

2 Teologiczny wkład Tischnera w charytologię omówiony został w: L. Wołowski, Łaska $i$ wolność u Hansa Ursa von Balthasara i Józefa Tischnera. W zakresie antropologii warto skonsultować: W. Baczyński, Człowiek jako istota dramatyczna w ujęciu ks. Józefa Tischnera, Papieski Wydział Teologiczny, Wrocław 2004; J. Jagiełł, W. Zuziak (red.), Człowiek wobec wartości, Znak, Kraków 2006. Jeśli chodzi o teologię pastoralną, to wdzięcznym tematem studiów są serie kazań i rekolekcji Tischnera, zob. np.: Nadzieja czeka na słowo. Rekolekcje, Znak, Kraków 2011; Rekolekcje paryskie, Znak, Kraków 2013; Szukajcie najpierw Królestwa Bożego. Wybór kazań starosądeckich, wyd. Andrzej Długosz, Stary Sącz 2007. Pokrewnym zagadnieniem jest tzw. religijna myśl Tischnera, zob. np. J. Jagiełło, W. Zuziak (red.), Między potępieniem a zbawieniem. Myślenie religijne ks. Józefa Tischnera, Znak, Kraków 2004.

\footnotetext{
3 J. Galarowicz, Ks. Józef Tischner, Petrus, Kraków 2013, s. 188.
} 
w wielu różnych miejscach - do tego stopnia, że można nawet mówić o specyficznej Tischnerowskiej mariologii - z całą pewnością jest jednak bardzo mało znany. Tischner bowiem nigdy nie uprawiał mariologii dla samej mariologii. Nie interesowało go badanie np. tytułów, dogmatów czy przywilejów maryjnych.

Jego mariologia nakierowana była zawsze na duszpasterską praktykę. W tym sensie doskonale wpisał się w postulat odnowy mariologicznej postawiony przez Sobór Watykański II w VIII rozdziale Konstytucji dogmatycznej o Kościele Lumen gentium ${ }^{4}$.

Refleksję mariologiczną Tischnera odnajdziemy więc np. w jego kazaniach i rekolekcjach, jak również $\mathrm{w}$ materiałach duszpasterskich, dotyczących takich zagadnień, jak pielgrzymka czy rachunek sumienia. Właśnie w tego typu pracach Tischner po mistrzowsku łączył opartą na Biblii głęboką refleksję mariologiczną z wynikającymi z niej wnioskami natury społecznej.

Przedmiotem badań obecnego opracowania będą trzy takie prace: jedno $\mathrm{z}$ adwentowych kazań Tischnera wygłoszonych w ramach cyklu o nieformalnym tytule Bóg nawiedza swój lud, Książeczka pielgrzyma, będąca jego refleksją nad jubileuszową pielgrzymką narodu polskiego na Jasną Górę oraz Pomoc w rachunku sumienia.

Tak się złożyło, że wszystkie te dzieła wydane są w bardzo słabo rozpowszechnionych, niskonakładowych wydaniach. Dostęp do niech jest zdecydowanie ograniczony, a zawarta w nich głębia myśli zarówno mariologicznej jak i społecznej zasługuje na zdecydowanie szerszy odbiór i poważną naukową dyskusję.

Warto pochylić się nad poruszonymi w tych dziełach problemami z co najmniej dwóch powodów. Pierwszy, to potrzeba ożywienia i rozwoju refleksji nad mariologią społeczną, tj. bardzo praktycznym odgałęzieniem mariologii, które w dużo większym stopniu niż dotychczas powinno brać udział w kształtowaniu społecznej nauki Kościoła. Drugi, to potrzeba odświeżenia spojrzenia na twórczość samego Tischnera, au-

${ }^{4}$ Komentarz do tego rozdziału i relację ze starcia dwóch wizji mariologii podczas soborowych obrad można znaleźć w: J. Ratzinger (Benedykt XVI), H.U. von Balthasar, Maryja w tajemnicy Kościoła, WAM, Kraków 2007, s. 9-20. W temacie tym warto też skonsultować: K Kowalik, Piąty dogmat?, w: tenże, Tradycja i otwartość. Księga pamiątkowa ku czci O. prof. S. C. Napiórkowskiego, Lublin 1999, s. 81-99. 
tora zazwyczaj zaszufladkowanego jako filozofa i ewentualnie miłośnika i promotora góralszczyzny, natomiast kompletnie nieznanego od strony swych niemałych przecież dokonań na polu innych, chociażby właśnie teologicznych dziedzin.

\section{BÓG NAWIEDZA SWÓJ LUD}

18 grudnia 1983 roku, kończąc cykl kazań adwentowych w kościele pw. św. Anny w Krakowie, Tischner wygłosił krótkie kazanie maryjne, które $\mathrm{w}$ swej tematyce stanowić będzie wprowadzenie do podjętych tu rozważań nad jego mariologią społeczną. W kazaniu tym zostały poruszone trzy podstawowe aspekty.

\subsection{ASPEKT SPOTKANIA}

Jednymi z najbardziej fundamentalnych kategorii, leżących u podstaw wszelkich relacji społecznych, są spotkanie i dialog. Tischner zagadnieniom tym poświęcił dziesiątki lat swej naukowej pracy ${ }^{5}$. Nie powinno więc dziwić, że także w tematyce mariologicznej zwrócił szczególną uwagę na te dwie kwestie.

Już sama myśl przewodnia wspomnianego cyklu kazań: Bóg nawiedza swój lud koncentruje się wokół problematyki spotkania (tu: Boga i człowieka), łącząc w sobie w perfekcyjny sposób zarówno społeczne (lud), jak i mariologiczne (nawiedzenie) nakierowanie.

Tischner zauważył, że paradygmatem spotkania i dialogu pomiędzy Bogiem i człowiekiem jest wydarzenie zwiastowania. Postawa, jaką przyjmuje w tej krótkiej ewangelicznej scenie Maryja, stanie się na wieki przedmiotem wnikliwych naukowych analiz i duchowych inspiracji.

Także studium Tischnerowskiej refleksji mariologiczno-społecznej należy rozpocząć od analizy tej właśnie sceny. Będzie ona jak refren powracać również i w dalszych analizach. Punktem wyjścia jest pozdrowienie

${ }^{5}$ Dość powiedzieć, że dwa flagowe dzieła Tischnera, tj. Filozofia dramatu, Znak, Kraków 2012 oraz Spór o istnienie człowieka, Znak, Kraków 2011, niemal w całości poświęcone są refleksji nad tą problematyką. 
i zapowiedź „wielkich rzeczy” (por. Łk 1,49), jakie Bóg czyni tym, którzy doznają łaski spotkania z Nim:

nasze adwentowe rozważania o tym, w jaki sposób „Bóg nawiedza swój lud”, zakończymy dziś rozważaniem o spotkaniu - spotkaniu z Bogiem. Tłem tego rozważania uczynimy zarysowany w Ewangelii obraz Zwiastowania. Przypominamy sobie poszczególne części obrazu. Spotkanie zaczyna się od pozdrowienia: „Bądź pozdrowiona Mario, łaski pełna. Pan $\mathrm{z}$ tobą. Oto poczniesz i porodzisz syna"6.

W przypadku Maryi tą „wielką rzeczą" będzie poczęcie i porodzenie, czyli przyniesienie na świat Syna Bożego. Wątek ten rozwiniemy poniżej, kiedy pochylimy się nad społecznym aspektem tego zagadnienia. $\mathrm{Na}$ razie pozostajemy jednak $\mathrm{w}$ ramach samej sceny zwiastowania. Następnym etapem, jaki wyróżni Tischner i uzna go za moment szczytowy, jest dialog.

Maryja nie jest biernym słuchaczem w scenie zwiastowania. Wchodząc $\mathrm{w}$ dialog z aniołem, a przez jego pośrednictwo z samym Bogiem, nakreśli ona $\mathrm{z}$ jednej strony wzorcowy model pełnego pokory i zaufania posłuszeństwa i gotowości do pełnienia woli Bożej: „Szczytowym momentem spotkania jest moment, w którym Maria mówi: «oto ja służebnica Pańska, niech mi się stanie wedle słowa twego»"7.

Z drugiej zaś, we wcześniejszej części tego dialogu (do której będzie jeszcze nawiązanie w dalszej części pracy), daje przykład odwagi, mądrości i przezorności w postaci postawionego przez siebie racjonalnego pytania (por. Łk 1,34).

Scenę zwiastowania zamyka motyw rozstania: „I odszedł od niej anioł"8. Motyw ten analizowany z różnych perspektyw kilkukrotnie pojawi się w dalszych częściach niniejszego studium.

Oprócz aspektu spotkania i dialogu Tischner wyróżnia jeszcze dwie podstawowe perspektywy czasowe, w jakich rozgrywa się scena zwiastowania: perspektywę przeszłości i perspektywę przyszłości.

6 J. Tischner, „Szukajcie...”, wyd. Kielecki Ośrodek Homiletyczny „Jedność”, Kielce [ca. 1985], s. 30.

7 Tamże.

8 Tamże. 


\subsection{PERSPEKTYWA PRZESZŁOŚCl}

Wydarzenie Zwiastowania nie wzięło się znikąd. Jest ono z jednej strony zbudowane na całej przeszłości Maryi, a $\mathrm{z}$ drugiej nadaje tej przeszłości zupełnie nowy wymiar i wydobywa z niej to, co najważniejsze:

Pan był z tobą wczoraj, przedwczoraj, od chwili poczęcia, a nawet wcześniej. On był z tobą już wtedy, gdy ciebie jeszcze nie było. Był i jest. Ale, co znaczy, że był i że jest? Znaczy, że - wybrał. Bóg, który stwarza, zarazem wybiera. [...] Anioł Zwiastowania rzuca owe światło w pamięć Marii. Dotychczas Maria pamiętała o większych lub mniejszych wydarzeniach swego życia. Odtąd będzie znać istotę własnej przeszłości. Jaką istotę? To, że „Pan z tobą”.

To, co najważniejsze, to wybór i trwanie. Nie tylko Maryja zostaje wybrana, lecz także i ona dokonuje wyboru: „Jeśli Maria odmówi, Słowo nie stanie się ciałem"10. Nie tylko jednak dokonuje wyboru, lecz także w nim trwa. Nie ma tu mowy o wycofaniu się. W tym momencie otwiera się aspekt społeczny zagadnienia:

To wszystko rzuca nowe światło na nasze spotkania z ludźmi. Nasze życie jest wypełnione spotkaniami. Spotykamy ludzi i ludzie nas spotykają. Wybieramy i ludzie nas wybierają. W życiu naszym pojawiają się również rozstania. Rozstanie to - wycofanie się z wyboru. Inne rozstania się nie liczą. Dopóki wybór nie zostanie odwołany, nie ma rozstania. ${ }^{11}$

Tischner wyłapuje tu istotną różnicę: $\mathrm{w}$ przeciwieństwie do typowych dziś standardów życia społecznego, w życiu Maryi, w którym nie brakowało zwykłych rozstań (jak chociażby opisane powyżej rozstanie $\mathrm{z}$ aniołem zwiastowania) nie było miejsca na rozstanie, w sensie wycofania się $\mathrm{z}$ raz podjętego wyboru.

\footnotetext{
9 Tamże, s. 30-31.

10 Tamże, s. 31.

11 Tamże, s. 32.
} 


\subsection{PERSPEKTYWA PRZYSZZOŚCl}

Ale jest jeszcze druga perspektywa, związana z przyszłością. Kluczową kategorią społeczno-mariologiczną, na którą zwróci tu uwagę Tischner będzie zagadnienie podjęcia odpowiedzialności:

Anioł jest przecież aniołem Zwiastowania, a zwiastowanie to przede wszystkim przyszłość. „Oto poczniesz i porodzisz syna.... O cóż tu chodzi? $\mathrm{W}$ istocie rzeczy chodzi o przyjęcie nowej odpowiedzialności. Spotkanie jest wydarzeniem odpowiedzialności. Jakiej odpowiedzialności? Za co odpowiedzialności? Odpowiedzialności za istnienie Boga miedzy ludźmi ${ }^{12}$.

Widać wyraźnie, że nie chodzi tu o zwykły rodzaj odpowiedzialności: „Odpowiedzialność jest tu radykalna. Dotyka wprost obecności Boga wśród nas”"13. W sensie mariologicznym chodzi o dosłowne podęcie odpowiedzialności przez Maryję za wcielenie i zrodzenie Syna Bożego. Ale istnieje także przedłużenie tej maryjnej odpowiedzialności na aspekt społeczny. Okazuje się, że odpowiedzialność za uobecnianie Boga w świecie spoczywa na każdym człowieku. Każdy musi być gotowy na swoje spotkanie z Bogiem (nawiedzenie, zwiastowanie), od którego zależeć będzie, to w jaki sposób przyniesie on Boga na świat, tj. uobecni Go w historii:

Miarą obecności Boga w historii są dokonywane przez ludzi wybory Boga. Bóg będzie wśród nas o tyle, o ile wybrani wybiorą Boga. [...] Uczymy się odpowiedzialności, abyśmy mogli dobrze przeżyć to jedyne spotkanie naszego życia, od którego zależeć będzie zaistnienie Boga wśród nas ${ }^{14}$.

\section{KSIĄŻECZKA PIELGRZYMA}

Najobszerniejszym i najbardziej kompleksowym mariologicznym dziełem Tischnera, które jednocześnie zdecydowanie nakierowane jest na

12 Tamże, s. 31. Analizie różnych aspektów odpowiedzialności w refleksji Tischnera poświęcona jest monografia: L. Hagedorn, Z. Stawrowski, Guardini - Tischner. Dramat odpowiedzialności. Drama der Verantwortung, IMJT-BWV, Kraków-Berlin 2013.

13 J. Tischner, „Szukajcie...”, s. 31.

${ }_{14}$ Tamże, s. 31-32. 
aspekt społeczny, jest jego refleksja zawarta w niewielkim dziele pt. Ksiażeczka pielgrzyma, poruszającym problematykę narodowej pielgrzymki, odbywającej się w 1982 r. dla upamiętnienia 600-lecia przybycia na Jasną Górę obrazu Matki Boskiej Częstochowskiej ${ }^{15}$.

Wątek społeczny zawarty w tym dziele siłą rzeczy zdominowany był przez ówczesną sytuację w kraju, zwłaszcza przez obowiązujący w tamtym czasie stan wojenny. Już w pierwszych słowach daje się wyczuć specyficzny klimat, w jakim powstawało:

Człowiek jest istotą pielgrzymującą. Znaczy to, że człowiek wędruje a wędruje dzięki jakiejś nadziei, która nie tylko podtrzymuje go w jego wędrówce, ale również w ogóle umożliwia mu życie. Żyć dzięki nadziei znaczy: być sercem w przyszłości. [...] Czym byłby człowiek bez nadziei? Byłby więźniem - więźniem miejsca i czasu. Dlatego mówimy także, że nadzieja wyzwala. Tak, to prawda. Pierwszym dziełem nadziei jest wyzwolenie. Człowiek zrywa kajdany ${ }^{16}$.

Aspekt mariologiczny nie stanowił głównego przesłania tego dzieła, był jednak czymś w rodzaju teologicznej kanwy, na bazie której krakowski myśliciel snuł swoje rozważania. Podobnie jak w przypadku omówionego już wcześniej kazania podstawowym rdzeniem mariologicznej refleksji Tischnera będzie tu scena zwiastowania. Wątek społeczny obracać się będzie wokół zagadnienia nadziei, która w zastosowanym przez Tischnera obrazie pielgrzymki nabierze znaczenia swoistego mariologiczno-narodowego drogowskazu dla umęczonego narodu:

Oto scena zwiastowania. Przyszedł Anioł do Maryi, która była pielgrzymem na ziemi. Przyszedł i jeszcze bardziej umocnił w Niej pielgrzymowanie. Odkrył jednocześnie, że odtąd będzie pielgrzymować z Synem, niosąc z Nim krzyż. „Oto poczniesz i porodzisz syna”. Na Jej drodze pielgrzymowania ma się urodzić Syn człowieczy. To wielka wskazówka dla nas. Na drodze naszego pielgrzymowania ma się także urodzić nowy człowiek. [...] Idąc ku Królowej Korony Polskiej, niesiemy jako dar

${ }^{15}$ Dzieło to ukazywało się w różnych wydaniach w latach 1982, 1990 oraz w 1996. Wszystkie odwołania w niniejszej pracy dotyczą wydania: J. Tischner, Książeczka pielgrzyma, wyd. Libellus, Warszawa 1996.

16 Tamże, s. 9. 
nadzieję na nowe człowieczeństwo w nas i nową w nim, rzetelniejszą i prawdziwszą polskośćc ${ }^{17}$.

Od razu rzuca się w oczy symetryczne uzupełnienie refleksji omówionej w poprzednim rozdziale. Tam podstawowym społecznym zadaniem człowieka „odziedziczonym” po Maryi było przyniesienie i uobecnienie Boga $\mathrm{w}$ świecie. Tu podstawowym zadaniem pielgrzymów, realizowanym jak gdyby wraz z Maryją, będzie „urodzenie nowego człowieka”, czyli duchowe nawrócenie i odrodzenie zakotwiczone w ewangelicznej idei „powtórnych narodzin” (por. J 3,3) ${ }^{18}$.

Tę maryjno-pielgrzymkową refleksję Tischnera przeanalizujemy poniżej szczegółowo, grupując ją w trzy podstawowe zakresy zagadnień.

\subsection{UBÓSTWO, PŁACZ I POKORNE MILCZENIE MARYI I PIELGRZYMÓW}

Rozpoczynając refleksję nad maryjną pielgrzymką narodu, Tischner zwraca uwagę na ważne pod względem społecznym właściwe zrozumienie pojęcia ubóstwa. Bez rozeznania, na czym polega prawdziwe, tj. rzetelne ubóstwo - w odróżnieniu od nędzy, biedy czy tzw. „dziadostwa”, nie można być prawdziwym pielgrzymem. Podobnie $\mathrm{w}$ drugą stronę - nie może być pielgrzymem ktoś, kto ma przed oczami jedynie bogactwa materialne ${ }^{19}$.

Kluczowy dla tej refleksji będzie aspekt mariologiczny. Gdy w perspektywie pielgrzymki mowa jest o ubóstwie, to chodzi tu o coś więcej niż tylko o różnego rodzaju braki materialne, jakich doświadcza pielgrzym i jakich niejednokrotnie doświadczała w swym życiu Maryja. Dla krakowskiego myśliciela nie to jest tutaj najważniejsze. Wskazuje on na: „ubóstwo płynące ze spotkana”20.

17 Tamże, s. 11-12.

18 Tę zadziwiającą symetrię dostrzega także Hans Urs von Balthasar, kiedy pisze o „wszechosobowym”, a nie tylko maryjnym wymiarze „złożenia Bożego zarodka w ludzkiej substancji”, który staje się „zaczynem” i dzięki któremu „Zakwaszona i uświęcona zostaje całość ludzkiej natury”. Cała ludzkość ma więc przynosić na świat Boga, rodząc się jednocześnie do nowego człowieczeństwa (por. H. Urs von Balthasar, Medytacja chrześcijańska, tłum. W. Szymona, „W drodze”, Poznań 2014, s. 53).

19 Zob. J. Tischner, Książeczka pielgrzyma, s. 13.

20 Tamże, s. 14. 
Ponownie powraca tu kwestia spotkania. W rozumieniu Tischnera to dopiero spotkanie odsłania prawdziwe ubóstwo człowieka, który - tak jak Maryja wobec anioła Gabriela - nie ma czym odwdzięczyć się za dobra, jakie w spotkaniu otrzymał. Ale z drugiej strony, to właśnie spotkanie staje się źródłem wielkiego bogactwa: „Prawdziwym skarbem pielgrzyma jest spotkany na drodze człowiek"21.

Ważny jest społeczny wniosek, jaki Tischner wyciąga $z$ tych rozważań. Adekwatność tego wniosku w czasach stanu wojennego była bezdyskusyjna. Wydaje się jednak, że posiada on ponadczasowy wymiar ogólnospołeczny:

Jesteśmy narodem, który pielgrzymuje - pielgrzymuje w ubóstwie. Słyszy się czasem, że nasze dzisiejsze ubóstwo jest naszym przekleństwem. $\mathrm{Z}$ pewnością jest $\mathrm{w}$ tym dużo racji. Ale czy ubóstwo to nie może być naszą szansą? [...] Czy nie ma w tym dla nas jakiejś wskazówki? Gdzie właściwie powinniśmy umieścić nasz narodowy skarb? Skoro nie możemy umieścić go w rzeczach, widać trzeba, abyśmy go umieścili w ludziach ${ }^{22}$.

Warto wrócić teraz na moment do tego bardziej materialnego aspektu ubóstwa przeżywanego przez pielgrzymów, którzy muszą borykać się z różnymi niedostatkami i trudnościami. Sytuacje te mogą doprowadzić pielgrzyma do smutku, a nawet płaczu. Dla Tischnera pielgrzymka, by nie stracić swej podstawowej wartości, niezależnie od poniesionych trudów i ofiar, doświadczonego smutku i łez, musi zawsze pozostać drogą nadziei.

I tak jak poprzednio $\mathrm{w}$ spotkaniu $\mathrm{z}$ jednej strony ujawniało się ubóstwo duchowe człowieka, ale $\mathrm{z}$ drugiej otwarła się przed nim perspektywa prawdziwego, bo międzyosobowego bogactwa, tak i tym razem w spotkaniu i w rozstaniu z drugim człowiekiem - zarówno w przypadku Maryi, jak i każdego pielgrzyma - nadzieja pozwala przeżyć i dostrzec nie tylko smutek, ale też obietnicę:

Nadzieja przychodzi do człowieka wraz z drugim człowiekiem. Bo człowiek jest dla człowieka zawsze zarazem spełnieniem obietnicy i obietnicą.

21 Tamże, s. 15.

22 Tamże, s. 15-16. 
Kimś takim był właśnie dla Matki Chrystus. I Matka dla Chrystusa także, bo matka z natury jest wielką obietnicą. Lecz oto płynął czas. Trwało pielgrzymowanie. Przyszła chwila rozstania. [...] Tak wygląda potwierdzenie obietnicy. To, co wydaje się oddalać, wróci. Miłość prawdziwa nigdy się nie oddala, jest mocna - mocniejsza niż śmierć23.

Nadzieja pielgrzyma, jak nadzieja Maryi, może i musi być silniejsza niż rozstanie i mocniejsza niż śmierć. Ale ta nadzieja najpierw sama musi się narodzić. Pielgrzymka stwarza ku temu warunki poprzez oderwanie od zgiełku codziennego życia i możliwość wkroczenia w przestrzeń ciszy i milczenia.

Maryja stanowi tu niedościgniony przykład. Po raz kolejny powrócić tu trzeba do sceny zwiastowania, podkreślając tym razem przenikający ją aspekt milczenia, dzięki któremu powstała przestrzeń, w której mogły wydarzyć się prawdziwie wielkie rzeczy: „Dopiero w głębi takiego milczenia może zabrzmieć słowo zwiastowania i słowo odpowiedzi” ${ }^{24}$.

To, co jest powodem milczenia Maryi, to jej głęboka i szczera pokora. Tam jednak, gdzie było to absolutnie konieczne i wynikało ze szczerej potrzeby poznania prawdy, potrafiła to milczenie odważnie przerwać. Tischner nawiązał do tego epizodu w omawianym już wcześniej kazaniu: „Maria ma swobodę wyboru. Nie lęka się wzbraniać, «Jak się to stanie, skoro męża nie znam». Anioł nie czuje się wzgardzony. Tłumaczy, wyjaśnia. Wybranym dane jest rozumienie Bożych tajemnic" 25 .

Mamy tu do czynienia z ciekawym sprzężeniem zwrotnym. Ten, kto zna tajemnice Boże, wie kiedy zapytać, ale właśnie dlatego je zna, bo nie boi się postawić pytania. Warto teraz prześledzić, jakie przełożenie społeczne ma taka właśnie postawa Maryi. Tischner zauważy tu analogię do postawy całego narodu, który wie kiedy z odwagą trzeba stać na baczność, a kiedy z pokorą zamilknąć i uklęknąć:

Pokorny naród wie przed jaką prawdą uklęknąć, a przed jaką stanąć na baczność. I wie również ku jakiej prawdzie pielgrzymować. [...] Wiadomo było, że trzeba od czasu do czasu klęknąć na drodze pielgrzymowania, by

\footnotetext{
23 Tamże, s. 22-23.

24 Tamże s. 18-19.

25 J. Tischner, „Szukajcie...”, s. 31.
} 
poprzez milczenie pokory usłyszeć słowa Zwiastowania. Nie dla strachu klęka wówczas Naród, ale z szacunku dla prawdy ${ }^{26}$.

\subsection{SPRAWIEDLIWOŚĆ, PRACA I MIŁOSIERDZIE W ŻYCIU MARYI I W ŻYCIU PIELGRZYMÓW}

Nie można się dziwić, że w kontekście wydarzeń stanu wojennego, jakie działy się w Polsce w 1982 r., Tischner dokonuje interpretacji zagadnienia sprawiedliwości w kontekście niesprawiedliwości, jaka panowała wówczas w dziedzinie ludzkiej pracy i jaka dotykała człowieka pracującego. Jego rozważania mają tu więc na wskroś charakter społeczny.

Wątek mariologiczny rodzi się zaś w kontekście całej serii poniżeń i niesprawiedliwości jakie dotykały św. Rodzinę ${ }^{27}$. W jej życiu odbija się jak w zwierciadle pragnienie i łaknienie sprawiedliwości społecznej tych, którzy na każdym etapie dziejów doznają krzywdy na drodze swojego życiowego pielgrzymowania. Z całą pewnością refleksja Tischnera miała swój wyjątkowo dramatyczny wydźwięk w okresie stanu wojennego, ale także i dziś następujące słowa pozostają nadal aktualne:

Krzywdzący spychają skrzywdzonych coraz niżej i niżej. Odmawiają im miejsca obok siebie, odmawiają im Ojczyzny, aż w końcu - gdy wyczerpią się siły krzywdzonych - odmawiają im również życia. [...] Im głębiej spychany jest człowiek, tym mocniejsze wołanie o sprawiedliwość wydobywa się z jego serca. [...] Kto na taki apel nie odpowiada, dowodzi zatwardziałego serca i sam staje się w jakimś stopniu współwinnym ${ }^{28}$.

Prawdziwy pielgrzym, tak jak Maryja i Józef, nie zatrzymuje się na rozpamiętywaniu doznanej krzywdy, nie szuka zemsty i rozliczeń. $\mathrm{W}$ przeciwnym razie zatrzymałby się $\mathrm{w}$ drodze, a kto wie czy nawet i nie pobłądził. Iść do przodu, to znaczy przejść od prostego pragnienia sprawiedliwości do dużo bardziej wymagającej postawy miłosierdzia. Wymiar społeczny tego zagadnienia Tischner stara się nakreślić w perspektywie przypowieści o miłosiernym samarytaninie:

\footnotetext{
26 Tenże, Książeczka pielgrzyma, s. 20.

27 Zob. tamże, s. 26.

28 Tamże, s. 27.
} 
Zadanie drugie jest trudniejsze. Postawmy pytanie: a czy ci, którzy zawinili okrucieństwem także zasługują na miłosierdzie? Czy raczej należy ich potraktować tak, jak oni traktowali innych? Ich nędza i bieda nie jest tak jaskrawa, jak rany leżącego przy drodze przechodnia. Oni często sami nie wiedzą, jacy są. Ich ukryty ból nie budzi litości. Ich widok napawa odrazą ${ }^{29}$.

Chcąc dać wskazówkę, jak należałoby podejść do tego wyjątkowo trudnego wyzwania społecznego, krakowski myśliciel stara się nadać mu wymiar mariologiczno-apostolski. Stara się tym samym zasugerować, że naśladując w tym względzie Maryję, naród może stać się społecznością prawdziwych apostołów Chrystusa:

I może właśnie to jest to polskie miłosierdzie, które jest dziś naszym dziejowym wyzwaniem - wyzwaniem płynącym z serca naszej Królowej Matki, zwanej przez Kościół Matką Miłosierdzia. Miłosierdzie bowiem otwiera wrota apostolstwu. Jeśli więc patrząc na polskie miłosierdzie odkryłeś już Marii Matkę Miłosierdzia, wiedz, że to dopiero początek Ona jest także Królową Apostołów ${ }^{30}$.

\subsection{OGLĄDANIE BOGA, POKÓJ I OFIARA, BĘDĄCE UDZIAłEM MARYI I PIELGRZYMÓW}

Dla Tischnera, czyste serce jest „zdolnością ducha do odkrywania Boga we wszystkim, co jest $\mathrm{w}$ nas i wokół nas"31. Krakowski myśliciel zauważa jednak, że nie każda próba odkrycia, czy szukania Boga wypływa $\mathrm{z}$ czystych pobudek. $\mathrm{Z}$ punktu widzenia postaw społecznych motywy i cele mogą być tu bardzo różne:

Rozmaite są cele szukania Boga w historii. Jedni szukają po to, alby móc zrozumieć historię. Tymi powoduje ciekawość badacza; doświadczyli skutków, chcieliby poznać przyczynę. Inni pragną poznać przyszłość; szukają Boga, by w Bogu oglądać to, co będzie. Jeszcze inni chcieliby

\footnotetext{
29 Tamże, s. 34.

30 Tamże.

31 Tamże, s. 35.
} 
zapanować nad historią. Ale na próżno. Historia skrzętnie zasłania swe tajemnice przed tymi wszystkimi i żaden $\mathrm{z}$ nich nie pozna Boga $\mathrm{w}$ historii ${ }^{32}$.

Na pierwszy rzut oka nie jest to zbyt optymistyczna wizja. Czyżby ludzkość w swych społeczno-historycznych wysiłkach skierowanych na szukanie Boga była skazana na niepowodzenie? Tischner z pewnością tego nie twierdzi. Powtórzy jednak jeszcze raz z naciskiem: „aby zobaczyć Boga, trzeba mieć czyste serce" 33 .

Trudno o czystsze serce niż to, które posiadała Maryja. Żeby więc odkryć, jaką postawę musi przyjąć człowiek, który szczerze pragnie szukać i znaleźć Boga, trzeba zapytać się, jaka postawa Maryi otworzyła ją na zdolność odkrywania Boga. Innymi słowy, trzeba dociec, jaka postawa zapewniała Maryi zachowanie w czystości jej serca. Po lekturze hymnu Magnificat Tischner dochodzi do nietuzinkowego wniosku, że postawą tą była postawa służby: „Bo wejrzał na uniżenie Służebnicy swojej. Oto bowiem błogosławić mnie będą odtąd wszystkie pokolenia” (Łk 1,48). Maryjna postawa pokornej, codziennej służby, tj. podejmowania swojego obowiązku, jest kluczem do utrzymania w czystości swego serca, a jednocześnie do poznania Boga: „W głosie obowiązku mówi i woła Bóg. Jaki Bóg? Bóg czystego serca" 34 .

Postawa pokornej służby oczyszcza serce i otwiera na Boga. Nie oznacza to jednak, że rozwiewa wszystkie ciemne chmury, jakie gromadzą się nad pielgrzymem w czasie jego drogi. Nie można bowiem zapominać o tym, że niezależnie od przyjętej postawy na drodze pielgrzymki w takiej czy innej formie, wcześniej czy później, spotkać się trzeba z problemem nieszczęścia i krzyża. Krzyż był nieodzownym elementem pielgrzymki Maryi i jej Syna:

I wiemy dobrze: nie pierwsi idziemy drogą krzyża: - poprzedza nas wielu, poprzedza Chrystus i ta, która powiedziała: „... Oto ja służebnica Pańska”. Idziemy ścieżką wydeptaną. [...] Byłoby czymś głupim i tragicznym, gdyby ktoś chciał od tego krzyża uciec. Nie dokona niczego więcej, jak tylko przemiany jednego krzyża w drugi, ale krzyża jako takiego nie zrzuci ${ }^{35}$.

\footnotetext{
32 Tamże, s. 37.

33 Tamże, s. 36.

34 Tamże, s. 37.

35 Tamże, s. 42.
} 
Tischner dokonuje w tym kontekście subtelnego rozróżnienia: krzyż i nieszczęście to nie to samo. Nieszczęścia mają charakter przypadkowy i niezrozumiały. Krzyż jest natomiast wartością wpisaną w istotę pielgrzymki: „Krzyż to coś nieskończenie więcej niż nieszczęście. Krzyż jest świadectwem. Świadectwo to głosi: istnieją wartości mocniejsze i wyższe od tych, z których ogałaca nas nieszczęście" 36 .

Tischner doda jeszcze, że krzyż oczyszcza z pychy. Posiada więc razem z postawą służby właściwości oczyszczające serce i pozwalające lepiej wniknąć w tajemnice Boga. Stopniowe oczyszczanie i coraz głębsze poznawanie Boga prowadzą pielgrzyma do celu jego pielgrzymowania. Celem tym jest osiągnięcie pokoju serca. By cel ten osiągnąć ostatnim etapem pielgrzymki musi być wyznanie win:

Zbliżamy się w pielgrzymowaniu naszym do stóp Królowej Polski. Raz jeszcze rzućmy okiem na przebytą drogę. Spójrzmy wstecz po to, aby w syntetyczny sposób ujrzeć naszą dziejową winę i aby tu, u stóp Królowej Pani, wyznać ją w pokorze. Nie lękajmy się tego wyznania. Pierwszym aktem wyzwolenia jest wiara $\mathrm{w}$ przyszłość, aktem ostatnim jest oczyszczenie $\mathrm{z}$ minionych win $^{37}$.

Kresem życiowej pielgrzymki powinno być osiągnięcie pokoju jako syntezy wszystkiego, przez co przeszło się na pielgrzymim szlaku: „W słowie «pokój» zawiera się jakby synteza wszystkiego, o czym mówią błogosławieństwa" ${ }^{38}$. W ten sposób maryjna pielgrzymka Tischnera, która stała się drogowskazem dla maryjnej pielgrzymki narodu, dotarła do swego kresu:

Tak kończy się dziś nasze pielgrzymowanie. Stajemy przed ołtarzem Królowej Polski w tym niezwykłym roku jubileuszowym. [...]. Na naszych nogach niesiemy kurz ziemi polskiej. Na naszych rękach i czołach są ślady naszej pracy. W naszych sercach niesiemy miłość naszą. Prosimy Królową Matkę, by była dla tej miłości Opiekunką i Ochroną. Przyszliśmy. Jesteśmy. „Swojemu Synowi nas oddawaj...” ${ }^{39}$.

\footnotetext{
36 Tamże, s. 42.

37 Tamże, s. 46.

38 Tamże.

39 Tamże, s. 49.
} 


\section{POMOC W RACHUNKU SUMIENIA}

Ostatnią pracą Tischnera, w której wątek mariologiczny przeplata się wyraźnie z wątkiem społecznym, jest niewielka książeczka pt. Pomoc $w$ rachunku sumienia. Może ona być rozumiana jako bezpośrednia kontynuacja poprzednio omówionej lektury. Tamta skończyła się na wyznaniu win uczynionym celem osiągnięcia pokoju serca. Ta pokazuje jak dokonać rachunku sumienia, by to wyznanie było głębokie i owocne.

Od samego początku przeplatają się tu ze sobą dwa wątki: indywidualny i społeczny. W kontekście pielgrzymki była mowa o tym, że pielgrzym nie może zatrzymać się na rozliczaniu innych, gdyż inaczej przestałby pielgrzymować. Musi jednak od czasu do czasu przystanąć, by rozliczyć siebie:

O tym że na świecie jest wiele zła, wiemy wszyscy. Często robimy rachunek sumienia światu. Szczególnej odwagi i dojrzałości potrzeba jednak do tego, by w ogromnej rzece zła wykryć maty strumyk, którego początki są we mnie; nie byłoby tego strumyka, dyby nie było mnie. Jestem początkiem, częścią rzeki, zgrzytem w harmonii. Odkrycie takie jest początkiem osobistego rachunku sumienia. Przestajemy rozliczać świat, a zaczynamy rozliczać siebie ${ }^{40}$.

Cały rachunek sumienia Tischner konstruuje wokół zagadnienia miłości, gdyż jest ono pierwszym i najważniejszym przykazaniem, jakie pozostawił nam Chrystus i jakie realizowała w swym życiu Maryja. Pod względem strukturalnym krakowski myśliciel odwoła się tu do klasycznego trójpodziału miłości wynikającego z jej trójrelacyjności. Będzie więc chodziło kolejno o nasz: „stosunek do Boga, stosunek do bliźnich, stosunek do siebie samego" ${ }^{41}$.

\subsection{STOSUNEK DO BOGA}

Pytanie o stosunek do Boga Tischner umieszcza w perspektywie pytania o wiarę. $\mathrm{W}$ ramach tej perspektywy dostrzega on wątek mario-

${ }^{40}$ J. Tischner, Pomoc w rachunku sumienia, Znak, Kraków 2000, s. 7-8.

41 Tamże, s. 14. 
logiczny, który pozwala mu zobrazować dwie wielkie tradycje dotyczące relacji wiary i rozumu:

W tradycji Kościoła pojawiały się dwie formuły, które odsłaniały głębiej dojrzewanie chrześcijańskiej wiary: „wiara szuka zrozumienia” i „rozumienie szuka wiary”. Przykładem wiary szukającej rozumienia jest Maryja Panna, która podczas zwiastowania postawiła aniołowi pytanie: „Jak mi się to stanie"?. Przykładem rozumienia, które szukało wiary, była postać Nikodema wsłuchującego się w nauki Chrystusa ${ }^{42}$.

Mamy tu do czynienia $\mathrm{z}$ oryginalnym zestawieniem dwóch postaw: postawy Maryi, która wychodząc od wiary szuka rozumienia, i postawy Nikodema, który wychodząc od rozumienia pragnie dotrzeć do wiary.

Przechodząc do interpretacji społecznej tego zestawienia, trzeba zauważyć, że Tischner nie stawia tych dwóch postaw we wzajemnej opozycji. Rachunek sumienia nie ma polegać na tym, że każdy musi porównać się do obu tych biblijnych postaci i jeśli stwierdzi, że bliżej mu do Maryi, to dobrze, a jeśli przeciwnie, to źle. Wyzwaniem jest dokonanie mądrej integracji obu tych postaw w życiu:

Trzeba jednak powiedzieć, że w codziennym życiu religijnym te dwie postawy zazębiają się i krzyżują. Są sprawy, w które wierzymy, choć nie do końca je rozumiemy, i są sprawy, które rozumiemy, a rozmienienie to jest odskocznią dla naszej wiary. Czasem nasza wiara szuka rozumienia, czasem rozumnie szuka wiary. Jedno pozostaje istotne: związek wiary i rozumienia. Wiara i rozumienie to dwie duchowe moce, ściśle ze sobą powiązane ${ }^{43}$.

Natomiast błędem, którego należy się wystrzegać, jest popadnięcie w skrajność, czy to fideizmu, czy to czysto horyzontalnego racjonalizmu. Pamiętamy z poprzednich rozważań, że Maryja nie tylko bezgranicznie zaufała Bogu. Tam, gdzie było to potrzebne, stawiała również racjonalne pytania. Podobnie Nikodem, gdyby nie zaufał Chrystusowi, nie czułby potrzeby nocnej wyprawy na spotkanie z Nim po to, by zadawać $\mathrm{Mu}$ pytania. Tischner konkluduje: „Kto chce mieć samo rozumienie bez wiary,

\footnotetext{
${ }^{42}$ Tamże, s. 15.

43 Tamże.
} 
ten błądzi - i błądzi ten, kto chciałby wierzyć, nie próbując rozumieć. Tajemnie wiary nie zbijają rozumu, ale go uskrzydlają. Ani rozum nie powinien lękać się wiary, ani wiara rozumu" ${ }^{34}$.

\subsection{STOSUNEK DO BLIŹNICH}

Analizując stosunek do bliźnich, Tischner koncentruje się na relacjach małżeńskich i rodzinnych. Nie ma tu już bezpośredniego odniesienia do osoby Maryi, znajdziemy jednak istotny wątek mariologiczny w głębszym, nieco ukrytym sensie. Wątek ten rozpatrzeć należy w dwóch różnych aspektach.

Pierwszy aspekt dotyczy wizji pozytywnej: biblijnej wizji rodziny. Tischner zauważa, że „należy przypomnieć sobie biblijne teksty o rodzinie, o małżeństwie" 45 . Z jednej strony są to teksy nowotestamentalne, dotyczące św. Rodziny, która w osobach Jezusa, Maryi i Józefa staje się biblijnym wzorem chrześcijańskiego życia rodzinnego. Z drugiej zaś są to starotestamentalne teksty dotyczące pierwszych rodziców, ale z okresu zanim doszło do pierwszego grzechu. Związek kobiety i mężczyzny ma swój określony przez Boga cel:

niech będą płodni i niech czynią sobie ziemię poddaną. [..] „Czynić sobie ziemię poddaną" znaczy przede wszystkim zbudować na tej ziemi „dom”, by tu, wśród obcych żywiołów tego świata, mogła „zadomowić się" ludzka wolność. Dla człowieka bowiem być wolnym na tej ziemi to „być sobą u siebie”. Człowiek powinien jednak również pamiętać, że jego "prawdziwe mieszkanie” znajduje się dopiero w niebie. Ziemski dom ma być znakiem, symbolem "zadomowienia” w Bogu ${ }^{46}$.

Wątek „zadomowienia” się w Bogu i zbudowania domu rodzinnego, w którym z kolei będzie mogła „zadomowić” się wolność łączy w syntetyczny sposób dwa podstawowe społeczno-mariologiczne aspekty poruszone przy okazji analizy dwóch poprzednich dzieł: aspekt stawania

\footnotetext{
44 Tamże.

45 Tamże, s. 28.

46 Tamże, s. 28-30.
} 
się nowym (tj. Bożym) człowiekiem i aspekt przynoszenia na świat Boga (tj. Wolności).

Drugi aspekt obecnych rozważań dotyczy wizji negatywnej: grzechu popełnionego przez pierwszych rodziców. Na pierwszy plan wysuwa się tu wątek społeczny. Wychodząc z tej podstawowej protologicznej prawdy biblijnej, Tischner dokonuje diagnozy kondycji, w jakiej znalazły się dziś relacje społeczno-rodzinne:

Grzech pierworodny wprowadził głębokie zaburzenie w ludzką cielesność. Polega ono na oderwaniu cielesności od podstawowej nadziei, jakiej cielesność służy - nadziei potomstwa i domu. Ogołocona z nadziei i - co za tym idzie - miłości, cielesność została oddana w niewolę „pożądliwości” i wszystkim w niej zakorzenionym lękom. Jakieś „obce prawo” zamieszkało w ciele. [...] Mężczyzna i niewiasta nie są mężem i żoną, lecz co najwyżej „partnerem” i „partnerką” w związku, który niezależnie od tego, jaką mu nada nazwę, nie jest rodziną człowieka ${ }^{47}$.

Żeby tę negatywną wizję przezwyciężyć, trzeba ponownie spojrzeć na Świętą Rodzinę i pochylić się nad Hymnem o miłości św. Pawła. Wątek maryjny przebija tu z ukrycia poprzez dobrze znany od czasów Justyna i Ireneusza z Lyonu paralelizm rekapitulacyjny, w którym starotestamentalnej parze Ewie i Adamowi przeciwstawia się nowotstamentalną parę: Maryję jako „nową Ewę” i Chrystusa jako „nowego Adama”. „Obce prawo”, jakie zapanowało w sercach ludzkich po grzechu pierworodnym, zostaje wówczas zamienione na nowe, prawdziwe prawo miłości, o której pisze w swym hymnie św. Paweł. Tischner apeluje: „Pielęgnujemy miłość między innymi również poprzez medytację nad miłością. Mistrzowie życia duchowego polecają szczególnie metyzację nad Hymnem o miłości św. Pawła: «Miłość cierpliwa jest [...]»"48.

\subsection{STOSUNEK DO SIEBIE SAMEGO}

W tej części swych rozważań Tischner wyciąga $\mathrm{z}$ opisanych poprzednio zarówno jawnych, jak i ukrytych aspektów mariologicznych

\footnotetext{
47 Tamże, s. 30-32.

48 Tamże, s. 30.
} 
finalne wnioski natury społecznej. Kanwą, na której opiera swe rozważania jest problem naśladowania Chrystusa. Wiemy, że w niedościgniony sposób czyniła to w swym życiu Maryja. Krakowski myśliciel pyta jednak, jak ma to czynić zwykły człowiek, tak aby jednocześnie nie zatracił tej swojej zwykłej ludzkiej tożsamości:

Czy jednak obowiązek naśladowania Chrystusa i obowiązek bycia sobą nie są ze sobą sprzeczne? Naśladując innego, nie jestem sobą, lecz innym - tym, kogo naśladuję. [...] Do tego dochodzi jeszcze jedno niebezpieczeństwo: w naśladowaniu bardzo łatwo przekroczyć pewną granicę popaść $\mathrm{w}$ udawanie, a nawet parodiowanie. Zamiast chrześcijanina, który naśladuje Chrystusa, mamy wtedy „chrześcijanina”, który parodiuje Chrystusa, kompromitując siebie i swa wiarę ${ }^{49}$.

Wiemy, jak bardzo aktualny jest to problem. W dzisiejszych warunkach społecznych spotykamy się często $\mathrm{z}$ dwoma skrajnie odmiennymi podejściami. Jedni twierdzą, że wymóg naśladowania Chrystusa nie jest dla nich i nie czując się "niepokalanie poczętymi” zostawiają tę postawę samej tylko Maryi. Inni z kolei na siłę starają się Maryi „dorównać” w jej świętości i wobec porażki takiego zamiaru popadają w zależności od charakteru we frustrację, w hipokryzję lub w pustą dewocję.

Tymczasem Tischner proponuje zupełnie inne podejście. Buduje bardzo ciekawą analogię, jaka zachodzi pomiędzy rzeczywistością prawdziwiej szczerej wiary a światem muzyki i sztuki:

„Naśladowanie” jest przeniesieniem pojęcia z dziedziny sztuki na dziedzinę wychowania. Grecy mówili, że na przykład taniec jest „naśladowaniem muzyki". Muzyka potrzebuje do swego istnienia czasu, taniec - przestrzeni. Jak można „przełożyć” czas na przestrzeń? Jak można znaleźć podobieństwo? A jednak artysta-tancerz potrafi: tańcząc, kroczy niejako „po śladach” muzyki. Coś podobnego ma się dokonać w religii, w naśladowaniu Chrystusa. Chrystus jest jakby muzyką, która brzmi przez wieki i pociąga ludzi do szczególnego „tańca”. „Ludzie patrzą na was i chwalą Boga, który jest w niebie" ${ }^{50}$.

49 Tamże, s. 38-39.

50 Tamże, s. $40-41$. 
W kontekście tej analogii Maryję nazwać można by Chrystuso wą Primabaleriną, a każdego z nas mniej lub bardziej utalentowanym uczestnikiem wielkiego Bożego balu.

\section{ZAKOŃCZENIE}

Z pewnością praca ta nie wyczerpała wszystkich społeczno-mariologicznych aspektów twórczości Tischnera. Warto kontynuować studium tego tematu w całej jego ogólności. Refleksja mariologiczna, nie tylko Tischnera, zawiera w sobie ogromny potencjał, który nie został jeszcze wystarczająco spożytkowany w naukach społecznych.

W swych rozważaniach Tischner często odwoływał się do tytułu Królowej Apostołów. Tytuł ten zawiera w sobie kwintesencję Tischnerowskiej mariologii społecznej. Chrześcijanin, który jest współczesnym apostołem świata, musi znaleźć w swym życiu taki sposób naśladowania Chrystusa, aby z jednej strony był wiarygodnym jego świadkiem, a z drugiej pozostał sobą.

W najdoskonalszy sposób taki ideał apostoła zrealizowała Maryja. To, co ją charakteryzowało, to właśnie owo „bycie sobą”, będące jednocześnie „byciem dla”. Ten ideał apostolstwa jest jednocześnie ideałem świętości i ideałem zdrowego współżycia społecznego. Jednym słowem, ideałem „wchodzenia do nieba” z zachowaniem własnej tożsamości pośród normalnych spraw codziennej społecznej egzystencji, gdyż jak to mówił Tischner: „Nie wchodzi się do nieba w cudzym przebraniu” ${ }^{51}$.

\section{BIBLIOGRAFIA}

Baczyński W., Człowiek jako istota dramatyczna w ujęciu ks. Józefa Tischnera, Papieski Wydział Teologiczny, Wrocław 2004.

Balthasar, H.U. von, Medytacja chrześcijańska, tłum. W. Szymona, „W drodze”, Poznań 2014.

Hagedorn L., Stawrowski Z., Guardini - Tischner. Dramat odpowiedzialności. Drama der Verantwortung, IMJT-BWV, Kraków-Berlin 2013.

51 Tamże, s. 42. 
Jagiełło J., Zuziak W. (red.), Między potępieniem a zbawieniem. Myślenie religijne ks. Józefa Tischnera, Znak, Kraków 2004.

Jagiełło J., Zuziak W. (red.), Bądź wolność Twoja. Józefa Tischnera refleksja nad życiem publicznym, Znak, Kraków 2005.

Jagiełło J., Zuziak W. (red.), Człowiek wobec wartości, Znak, Kraków 2006.

Kowalik K., Piąty dogmat?, w: tenże, Tradycja i otwartość. Księga pamiątkowa ku czci O. prof. S. C. Napiórkowskiego, Lublin 1999, 81-99.

Ratzinger J. (Benedykt XVI), Balthasar H.U. von, Maryja w tajemnicy Kościoła, WAM, Kraków 2007.

Rogowski W., Dylematy liberalizmu: wokół myślenia politycznego Józefa Tischnera, DUET, Toruń 2013.

Stawrowski Z., Solidarność znaczy więź, IMJT, Kraków 2010.

Tischner J., Etyka solidarności, Znak, Kraków 1981.

Tischner J., Filozofia dramatu, Znak, Kraków 2012.

Tischner J., Jak żyć?, TUM, Wrocław 2000.

Tischner J., Książeczka pielgrzyma, Libellus, Warszawa 1996.

Tischner J., Nadzieja czeka na słowo. Rekolekcje, Znak, Kraków 2011.

Tischner J., Nieszczęsny dar wolności, Znak, Kraków 1996.

Tischner J., Pomoc w rachunku sumienia, Znak, Kraków 2000.

Tischner J., Rekolekcje paryskie, Znak, Kraków 2013.

Tischner J., Spór o istnienie człowieka, Znak, Kraków 2011.

Tischner J., „Szukajcie...”, wyd. Kielecki Ośrodek Homiletyczny „Jedność”, Kielce [ca. 1985].

Tischner J., Szukajcie najpierw Królestwa Bożego. Wybór kazań starosądeckich, wyd. Andrzej Długosz, Stary Sącz 2007.

Wołowski L., Łaska i wolność u Hansa Ursa von Balthasara i Józefa Tischnera, WAM, Kraków 2019. 